Globalization and Workforce Composition in Indian Formal Manufacturing: New evidence on product market competition channel

Ritabrata Bose and K.V. Ramaswamy

Indira Gandhi Institute of Development Research, Mumbai November 2020 


\title{
Globalization and Workforce Composition in Indian Formal Manufacturing: New evidence on product market competition channel
}

\author{
Ritabrata Bose and K.V. Ramaswamy \\ Email(corresponding author): swamy@igidr.ac.in
}

\begin{abstract}
A variety of mechanisms linking globalization and margins of adjustments in the labour markets have been empirically tested in recent years. How globalization could affect workforce composition of industries and thereby the quality of jobs, a key labour market indicator is much less studied and the econometric evidence is sparse. This study contributes to filling the gap by studying India's formal manufacturing sector that experienced deep trade and industrial reforms since the 1990s. Industrylevel panel data are analysed to establish the indirect link between product market structure (concentration) and workforce composition of firms (usage of contract workers). We explicitly measure changes in market concentration using a newly constructed trade-adjusted concentration ratio, profitability (price-cost mark-up) and workforce composition (usage of contract workers) to show how the effect of globalization is mediated indirectly through the product market structure. Our sample includes 46 three-digit formal manufacturing industries spanning from 1998 to 2014. The findings provide significant evidence that Indian manufacturing firms responded to globalization by hiring relatively more contract workers a key margin of labour market flexibility. This finding underlines the importance of understanding the indirect ways in which globalization could affect labour market conditions and workers welfare in developing countries.
\end{abstract}

Keywords: market concentration, price cost mark-up, contract labour, globalisation

JEL Code: D22, F60, F66, F16, D22 and L16 


\title{
Globalization and Workforce Composition in Indian Formal Manufacturing: New evidence on product market competition channel
}

\author{
Ritabrata Bose ${ }^{1}$ and K.V. Ramaswamy ${ }^{2}$
}

\begin{abstract}
A variety of mechanisms linking globalization and margins of adjustments in the labour markets have been empirically tested in recent years. How globalization could affect workforce composition of industries and thereby the quality of jobs, a key labour market indicator is much less studied and the econometric evidence is sparse. This study contributes to filling the gap by studying India's formal manufacturing sector that experienced deep trade and industrial reforms since the 1990s. Industrylevel panel data are analysed to establish the indirect link between product market structure (concentration) and workforce composition of firms (usage of contract workers). We explicitly measure changes in market concentration using a newly constructed trade-adjusted concentration ratio, profitability (price-cost mark-up) and workforce composition (usage of contract workers) to show how the effect of globalization is mediated indirectly through the product market structure. Our sample includes 46 three-digit formal manufacturing industries spanning from 1998 to 2014. The findings provide significant evidence that Indian manufacturing firms responded to globalization by hiring relatively more contract workers a key margin of labour market flexibility. This finding underlines the importance of understanding the indirect ways in which globalization could affect labour market conditions and workers welfare in developing countries.
\end{abstract}

Keywords: market concentration, price cost mark-up, contract labour, globalisation

JEL Codes: D22, F60, F66, F16, D22 and L16

\footnotetext{
${ }^{1}$ bose.rb7@gmail.com

${ }^{2}$ swamy@igidr.ac.in
} 


\section{Introduction}

"If Globalization is a Bowl of Cherries, Why are there so many glum faces around the table?" (Dani Rodrik, 1999)

Globalization, it is now widely accepted, has been the key factor underlying the observed pressure on labour markets in both developed and developing countries. A variety of mechanisms linking globalization and margins of adjustment in the labour markets have been empirically tested in the trade and development literature. The focus of empirical research has been essentially on measuring the direct effects of trade liberalization and globalization on labour demand, wages and wage inequality (relative wages of skilled and unskilled workers (Hasan, Mitra and Ramaswamy, 2007; Chamarbagwala, 2006; Goldberg and Pavcnik,2007; Dix-Carneiro and Kovak,2019). Much less attention has been paid to the indirect ways in which trade openness could affect the profitability and the quality of jobs within the formal sector or the so-called covered sector, consequently worker welfare in developing countries.

We have drawn attention to one possible indirect mechanism wherein the effect of globalization is mediated through changes in product market structure. In our set up, globalization affects the product market structure (the intermediate factor) and in turn impacts the profitability ${ }^{3}$ (the product market outcome) and the workforce composition (the labour market outcome). In empirical studies of globalization and labour, the changes in product market structure is not explicitly measured and shown to impact the labour market. A novelty of the present paper is that we study the impact of product market concentration changes, a measure of the market structure and competitive condition, on the workforce composition of industries. The workforce composition is defined in terms of the share of contract workers in total workforce, and which is one of the key margins of adjustment in labour markets. Increasing use of contract labour in Indian manufacturing recent years has been well documented. But studies have not shown the economic or the structural factor driving that change given the institutional and regulatory environment in India. Our paper is perhaps the first to demonstrate the empirical link between measures of product market competition and the intensity of contract labour usage in a globalizing developing country.

\footnotetext{
${ }^{3}$ In this paper, we will be using profitability and price cost markup interchangeably.
} 
The paper is organised as follows. Section 2 offers an overview of the product market in Indian manufacturing sector. Section 3 reviews the related literature and the following section, develops the hypothesis. Section 5 discusses the data. Section 6 gives the research methodology and Section 7 presents the results. Finally, Section 8 concludes the paper.

\section{Liberalization Policy and Indian Manufacturing Sector}

\subsection{Product Market}

Indian manufacturing sector has undergone a paradigm shift from a period of import protection, industrial capacity licensing, and price regulation to a liberalised market-oriented open economy. The pre-liberalisation, industrial policies were aimed at self-reliance, importsubstitution and a bias towards heavy industry (Table 1). The three main elements of economic policy until the 1970 s and to some modified extent in the 1980s have been (1) extensive bureaucratic controls over production, investment and international trade (2) inward-looking trade and foreign investment policies and (3) the presence of public sector enterprises in sectors other than those in traditionally expected like public utilities (Bhagwati, 1993). Before 1991, industry concentration patterns in India were an outcome of industrial policies that restricted entry and expansion of large domestic firms and new entry by foreign firms, through licensing and product reservation for small-scale firms. Further the Industrial Policy Resolution of 1956 reserved certain industries for state-owned firms, prohibiting the entry of any private firms. Until 1991, government approval was required for foreign direct investment (FDI) in all industries and services. In order to verify the proposition that barriers to entry rather than technological factors that determine scale explain the pattern of industrial concentration in India before 1991, Chari and Gupta (2008: 636) have compared the prereform industrial structure in India with that of the United States in the year 1990. They have found the average Herfindahl-Hirschman Index (HHI) in India was significantly higher $(40 \%)$ than in the United States $(24 \%)$ for the same three-digit SIC industries and more importantly industry concentration in protected industries in particular was significantly higher in the corresponding industry group in the US (54\% versus 22\%), just like the entry of 
firms, exit of firms were also controlled by a complicated set of regulations on factory closure and labour retrenchment. ${ }^{4}$

The industrial policy reforms initiated in the 1990s involved the following key measures: (1) Removal of legal barriers to entry and capacity expansion, takeovers and merger restrictions on large firms (2) Raising foreign equity participation and the entry of foreign enterprises into manufacturing. (3) Removal of protection to small-scale manufacturing units by restricting the entry of large firms into numerous specified products (that exceeded one thousand products at one time) and (4) Removal of restrictions on the use of foreign brand names and trademarks by domestic firms. ${ }^{5}$

\begin{tabular}{lll}
\hline \multicolumn{1}{c}{ Policy } & \multicolumn{1}{c}{ Description } \\
\hline Industries & (Development and & Licensing requirements were imposed for firms above \\
Regulation) Act, 1951 & a certain size in a specified list of industries \\
\hline Industrial Regulation Act, 1956 & $\begin{array}{l}\text { Private sector growth in some industries was } \\
\text { restricted through licensing and some sectors were } \\
\text { only reserved for state enterprises }\end{array}$
\end{tabular}

Monopolies and Restrictive Trade Restricted capacity expansion, opening of new Practices Act, 1969 enterprises and, takeover and merger activity of businesses with assets of more than Rs. 200 million and those of dominant undertakings (market share of more than 33 percent) with assets of more than 33 percent

Industrial Policy Statements, Made licensing mandatory for all firms above a 1973 certain size and some industries were reserved for small-scale firms

Foreign Exchange Regulation Foreign-owned firms were required to reduce equity Act, $1973 \quad$ stake to below 40 percent, with some exceptions

Industrial Policy Resolution, Expanded the industries list of small-scale firms to 1977 include additional 800 products.

Table 1: List of policies during 1950-84

\footnotetext{
${ }^{4}$ See Athreye and Kapur (2006) for an early and more detailed discussion of industrial concentration in Indian manufacturing and industrial policy. Their econometric analysis is based on balance sheet data collected by the Reserve bank Of India (RBI) and covered the period 1970 to 1999.

${ }^{5}$ Several authors have discussed these and other reform measures in the literature. See Hasan et. al. (2007), Alfaro and Chari (2010) and Panagariya (2008) and Ramaswamy (2006) among many other references.
} 
A series of major trade reform measures were undertaken by the Indian government in July 1991 that has greatly led to the simplification of the trade regime (Panagariya 2008). This included the removal of most licensing and other nontariff barriers on all imports of intermediate and capital goods, the reduction of tariff levels and their dispersion, and the full convertibility of the domestic currency for foreign exchange transactions. Tariff reductions took place in 77 industrial categories and tariffs across a wide range of industries fell from a simple average of about 85 per cent in 1990 to a value of approximately 12 per cent in 2007 (Panagariya, 2008) .The standard deviation of tariffs during this period went down from 41 percentage points to roughly 15 per cent. Moreover, substantial reduction of non-tariff barriers was also implemented. The exchange rate was also devalued however the importenhancing effect of the trade reforms more than offset the import-reducing effect of the exchange rate devaluation. ${ }^{6}$ In short the industrial and trade policy reforms in India has led to far reaching changes in the competitive conditions in the domestic market by increasing the threat of import competition and the threat of potential entry of foreign firms, and the entry of domestic private firms in different industries. In response to these policy changes the market structure has been observed to change in terms of market concentration and market shares. An important study of India observed that that industry concentration and average market shares declined in industries that experienced either de-licensing or FDI and/or trade liberalization (Alfaro and Chari, 2010: 204).

\subsection{Labour Market Structure}

Unlike the product markets the labour markets have not undergone substantial changes in the years following economic reforms in 1991. They have continued to be dualistic with a large informal sector where a large number work often without job contracts and job security regulation. The share of formal sector or the registered sector that covers all factories registered under the Indian Factories Act 1948 has been around 16 to 18 per cent of the total manufacturing workforce of around 60 million in recent years. ${ }^{7}$ This segment of little more than 10 million workers has been covered under different labour laws and social security benefits. Annual Survey of Industries (ASI) data shows that total workers employed in the organised manufacturing sector has increase from 5.8 million in 1998-99 to 10 million in 2014-15. On closer observation we find that the share of contract workers in number of

\footnotetext{
${ }^{6}$ Hasan et al (2007)

${ }^{7}$ The Annual Survey of Industries covers all factories registered under the Factories Act, 1948 and under the Bidi (Indian Cigarette) and Cigar Workers (Condition of Employment) Act, 1966, i.e. those employing 10 or more workers and using power and 20 or more workers but not using power.
} 
total workers (later described as contract intensity, CI) has increased from 15.7 per cent in 1998-99 to 35 per cent in 2014-15. Firms are found to favour employment of contract workers because they do not fall under the employment protection provisions of Indian labour laws and their average wages per day are lower relative to regular workers and they are subject flexible hiring and retrenchment conditions (more on this below). Labour laws of India have been the focus of extremely contentious debate, pinpointing the Industrial Disputes Act (IDA, 1947) and its various amendments that have made layoffs, retrenchments harder. Saha et al (2013) found that the use of contract workers has increased in states with stricter labour regulations and they call this outcome of the Indian labour market as imperfect flexibility.

Under Article 246 of the Constitution of India, labour is the subject in the Concurrent List. India being a federal democracy, Central and State governments both can enact legislations, and many labour laws have been enacted for different aspects of labour regulation. The central and state governments have powers to formulate rules in order to facilitate implementation of the labour laws. Among several legislations, the Industrial Disputes Act (IDA), 1947 deserves special attention and it stands at the core of all labour laws in India.

IDA of 1947 touches on various aspects like hiring and firing of workers, closure of establishments, strikes and lockouts in the formal sector. It established a three-tiered dispute resolution mechanism comprising of conciliation, arbitration and compulsory adjudication of labour disputes. The IDA was passed by the central government, but it has been amended several times by different state governments, based on which the states became more labourfriendly or employer-friendly depending primarily on how tough to hire and fire workers (job security). Chapter 5-A of the IDA requires notice and compensation for lay-off, retrenchment and closure if the firm employs not less than 50 workers. Third, Chapter 5-B requires notice, compensation and permission from government for lay-off, retrenchment and closure, if it employs more than 100 workers. Others like the Industrial Employment (Standing Orders) Act that lays down terms and conditions of work come into force if the firm employs more than 100 workers or the threshold level specified in the corresponding state law in which the firm is located. Section 5-B is stringent as it requires the firms to take prior permissions from the government in order to lay-off or retrench workers and it requires ninety days (sixty days in Sec 5-A) to close down operations with prior permission from the government. Both sections make firing of workers more costly. The size threshold is defined in terms of number 
of permanent workers in each factory whose names appear in its muster roll. In other words, non-permanent workers could be employed to stay below the legal cut-off size. The dominant category of non-permanent workers is the contract workers or workers employed through a contractor. IDA regulations do not cover contract workers as they are hired through contractors and not directly on the payrolls of the employing firms. ${ }^{8}$ Since contract workers are also not covered by trade unions, they are paid lesser wages (about 45 per cent of the regular workers' wage, according to Bhandari and Heshmati (2006) even if they are similar to the regular workers. The difficulties of legal interpretation of the term 'similarity of work' have made the enforcement of wage parity between regular and contract workers a weak provision of Indian labour law.

We will be analysing whether market concentration has any effect on the contract intensity. We observed that product market concentration has declines in recent years (Figure 2). In other words, product markets have experienced more intense competition. One of the key factors driving the growth of contract workers (Figure 5) could be greater cost competition in the product market. In the presence of labour regulations, the incentive to hire contract workers can be hypothesised to go up with the intensity of product market competition. Firms are expected to respond to greater competitive rivalry and cost competition in product markets by hiring more contract workers. Firms search for flexibility at the margin in production and labour practices as they encounter greater product market competition. Hiring contract workers is one of the key avenues of flexibility open to firms following greater openness to trade and potential competition due to ease of entry. This hypothesis has not been empirically tested in the literature on manufacturing employment in India. ${ }^{9}$

\section{Related Literature}

\subsection{Trade, informality and employment}

It is related to studies of trade reform and the incidence of informal employment in developing countries. Currie and Harrison (1997) in their study of manufacturing firms in Morocco demonstrated the existence of labour reallocation across sectors, depending on whether firms were facing increased competition following the trade reform. They found that

\footnotetext{
${ }^{8}$ Conditions of hiring and workplace conditions of contract workers are subject to a separate law called the Contract Labour Abolition and Regulation Act 1970 (CLAR 1970)

${ }^{9}$ See Ramaswamy (1999) for an early discussion of search of flexibility by manufacturing firms.
} 
firms started hiring more temporary workers after the completion of a comprehensive trade liberalization program. Acosta and Montes-Rojas (2014) paper studied the relationship between trade liberalisation and informality in Argentina. Using manufacturing industry level data for 1992-2003, their results confirm the hypothesis that trade increases informality in industries that experience sudden foreign competition.

The impact on informal employment could vary depending on the tightness of labour market regulations prevailing in the country as found in a study of Brazil and Columbia by Goldberg and Pavcnik (2003). In countries with weak enforcement of labour regulations firms have been observed to have greater flexibility in responding to trade liberalization. Goldberg and Pavcnik (2003, p. 464) argue that trade exposure increases pressure on firms 'to try to reduce labour costs by cutting worker benefits, replacing permanent workers with part-time labour, or subcontracting with establishments in the informal sector, including home-based and self-employed micro-entrepreneurs'.

It is connected to the literature on globalization and employment that investigates the impact of trade liberalization, Foreign Direct Investment (FDI) and global value chains (GVC) on employment. Recently, Dix-Carneiro and Kovak (2017) study the impact of trade reforms of the 1990s on employment in Brazil. They find that workers in the tradable sectors that faced larger tariff reductions had shorter spells of formal employment, while workers in non-tradable sectors were driven into informal employment Similarly, Menezes-Filho and Muendler (2011) find that Brazil's trade liberalization in the 1990s led to the displacement of formally employed workers from protected industries and that 'comparative advantage' industries or exporters did not absorb trade-displaced workers in full. Their complementary analysis of employment survey data reveals that many of these formally employed workers transitioned to informal work or self-employment. For others, trade liberalization was associated with transitions to unemployment.

\subsection{Trade and wage inequality}

The effects on workforce composition, the focus of the present paper, is directly related to papers that study the impact of globalization on employment, relative wages and social security (welfare) of workers in developing countries. The wage inequality question has been the subject of debate and empirical research since the 1990s (Goldberg and Pavcnik, 2007, ILO 2015, Helpman et al 2017 among others). 
However, the research in this area has been essentially focussed on measuring the direct effects of globalization on labour demand, wages and wage inequality (relative wages of skilled and unskilled workers). They have emphasized two alternative channels of transmission or links in their causal explanations. First, trade flows based on differences in relative factor endowments based on Hecksher-Ohlin and Stolper-Samuelson theory (H-O-S theory). The H-O-S theory assumed competitive product and factor markets and predicted that globalization of trade in goods generates demand for the relatively abundant factor (unskilled labour) and declining wage inequality. Empirical studies carried out in many developing countries have not supported this prediction. Troubling evidence has been the observed increase in relative wages of skilled workers and the resulting wage inequality in developing countries. The evidence suggests that new demand for labour due to opening up of the economies has benefited relatively educated (skilled) workers. Technological change, it has been argued could be skill biased (SBTC), that is, technological change biased against the use of unskilled labour. The new technology of production that flows in from industrialized countries through Foreign Direct Investment (FDI) and import of advanced capital goods have been argued to be skill-biased or unskilled-labour saving as they originate from capital rich countries. In other words, the drivers of technological change in developing countries may be embodied in 'imported capital good', for example, machines, office equipment and other capital goods that are complementary to skilled labour. Trade liberalization affects the demand for skilled labour by reducing the relative price of these capital goods and increasing their imports. SBTC may be an endogenous response to trade openness (Autor, 2003). In other words, globalization is indirectly held responsible for the observed inequality of relative wages of workers (Goldberg and Pavcnik 2007).

However, studies of wage inequality have not paid much attention to the role of product market competition which could directly impact relative wages. The study by Guadalupe (2007) may be considered as an exception. She has drawn attention to the interaction between competition in product markets and within sector wage inequality. In her study based on panel of UK workers covering the period 1975 to 1999, she finds that returns to skill within an industry increase with competition leading to greater wage inequality between skill and unskilled workers within an industry. She argues that industry competition increases the sensitivity of firm profits to cost savings (direct effect) therefore firms would hire more skilled workers who would contribute more due to their higher productivity that leads to greater wage inequality. 


\section{Price cost mark-up and workforce composition}

\subsection{Product market concentration and price cost mark-up}

Several studies have attempted to characterise the product market structure in Indian manufacturing in the pre-reform as well as the post reform years. They have broadly used the well-known Structure-Conduct-Performance (SCP) paradigm to investigate the changes in market structure and market outcomes like price-cost mark-ups or rates of return using different data sets and time-periods. ${ }^{10}$ This framework has yielded several empirical regularities and has proved to be useful in many policy and regulatory contexts. Kambhampati (1996) found that concentration was increasing during the pre-reform era. Similarly, Athreye and Kapur (2006) have found that concentration has either increased or remained the same most of the 53 three-digit industries during the period 1970-1999. As we noted earlier, Alfaro and Chari (2010) in their study based on the prowess Corporate data base found that the concentration measured by Herfindahl-Hirschman Index (HHI index) has declined in the years between 1988 and 2005. Similarly, Pal (2015) found using firm level data collected by the Reserve Bank India (RBI), that the price-cost-mark-up has decreased during the period 2001-2010 in Indian manufacturing as a whole and also reported procompetitive dynamics in terms of pricing behaviour in a majority of the 20 industry groups. However, a limitation of the empirical studies of the SCP paradigm is the non-accountability of foreign competition in the structure of the domestic industries. It is argued that imports into the domestic country have an impact on the structure of the domestic industries, but the exports do not play any role in the domestic industries' structure. It is evident from Figure 1 that India's import dependence (imports as a share of domestic demand) is more than that of the export penetration (exports as a share of total output) and the gap was widening for a long period of time. While much empirical work has been work done in the developing country context like India using the SCP paradigm all of them have considered the traditional trade unadjusted concentration measures like the CR ratios (CR4 and CR20) and the HHI. We have attempted to overcome this limitation by using trade-adjusted concentration measure to

\footnotetext{
${ }^{10}$ According to this paradigm, it is postulated that the at certain point in time performance of a market (measured by profit markup or rate of return) is affected by the structure of the market (measured by concentration, size of firms, number of firms, marketing intensity etc.) through conduct of economic agents (like cooperation/collusion, barriers to entry and foreign outwardness (Carlton and Perloff, 2005; Hay and Morris, 1991).
} 
(accurately) measure the structure of the industries, as devised by Bhattacharjea and Sindhwani (2014).

\subsection{Product market competition and workforce composition}

We suggest one possible analytical mechanism that could explain the likely effect of product market competition on workforce composition to motivate the study. Let us assume that manufacturing firms can hire either regular workers or it can hire workers through temping firms (US terminology) also called labour contractors in India. Notice that both worker types are unskilled with similar productivity. However, the employment of regular workers is regulated by labour market regulations and they receive many benefits. JSR require the firm to incur at least four types of costs: (i) administrative procedures for termination, (ii) advance notification, (iii) compensation for dismissal, and (iv) legal costs of a trial when the firm or the workers contest the decisions of the state authorities. In short, regular workers cannot be dismissed from service unless the firm has accumulated enough evidence. They will receive severance payment when dismissed (This is an inherited labour regulations and institutional set up in many developing countries including India). This implies that adjustment costs associated with the employment of such workers are higher relative to those associated with contract workers. Given this set up one could ask what happens if product market competition increases due to economic liberalization and globalization? Greater product market competition could lead to greater uncertainty of expected profits or could raise the probability of external shock to the firms in the industry raising their costs of labour adjustment. Then it can be argued that firms will have an incentive to set up a dual structure within the firm by employing unskilled-contract workers (so called Tier-II workers, who could be fired without cost) instead of regular workers (Tier-I workers). In short in response to greater competition the firms have incentive to increase the fraction of contract workers employed at each level of production. In other words, the expected cost savings from changing the workforce composition will be more valuable as competition increases in an industry. From the viewpoint of labour the share of contract workers in total workforce increases and the workforce composition has changed creating a more vulnerable workforce attributable to globalization. Whether the above analytical model holds good or not is an empirical question. This paper has attempted to provide some econometric evidence in support of the effects of product market competition on labour markets in the case of formal manufacturing sector in India. 


\section{Data}

We have compiled a NIC 3-digit industry level panel dataset consisting of 46 industries spanning from 1998 to 2014 based on the firm level data from the Prowess database and factory level data from the Annual Survey of Industries (ASI). The Prowess database, collected by Centre for Monitoring the Indian Economy (CMIE) contains information of about 5000 large and medium manufacturing firms, which is about 85 percent of the total registered manufacturing firms in India. The factory-level panel data comes from the Annual Survey of Industries (ASI), conducted by the Ministry of Statistics and Program Implementation (MOSPI) in India. The ASI covers all registered industrial units, which includes units with 10 or more workers and use electricity, or have least 20 workers but do not use electricity. This data set is well suited for this paper as it has employment broken down by permanent and contract workers at the factory level. Regular workers are those directly employed by the factory and enjoy job-security benefits. Contract workers are those employed by the factory through an intermediary, that is a labour contractor or agent and they are not on the muster roll of the factory. Total workers in a factory refer to the sum of regular and contract workers. Unlike the Annual Survey of Industries (ASI) database which contains data at the plant (factory) level, the Prowess data is based on balance sheet information of companies or firms with multiple factories. It is publicly available and considered as reliable database, and several studies have been done using Prowess database like Goldberg et al. (2010), Chari and Gupta (2008) among others.

We complement the data with industry-wise trade data (data on industry-wise total export and total import) from World Integrated Trade Solution (WITS) database. We have undertaken concordance between Prowess data which follows National Industrial Classification (NIC) 2008 and WITS data which follows International Standard Industrial Classification (ISIC) Revision 3 (equivalent to NIC 1998) to form a concorded data which follows NIC 2008.

\subsection{Descriptive statistics}

We have presented four figures that describe the trends in the movement of the variables central to our analysis. They are self-explanatory ${ }^{11}$.

\footnotetext{
${ }^{11}$ More detailed descriptive statistics would be made available on request
} 


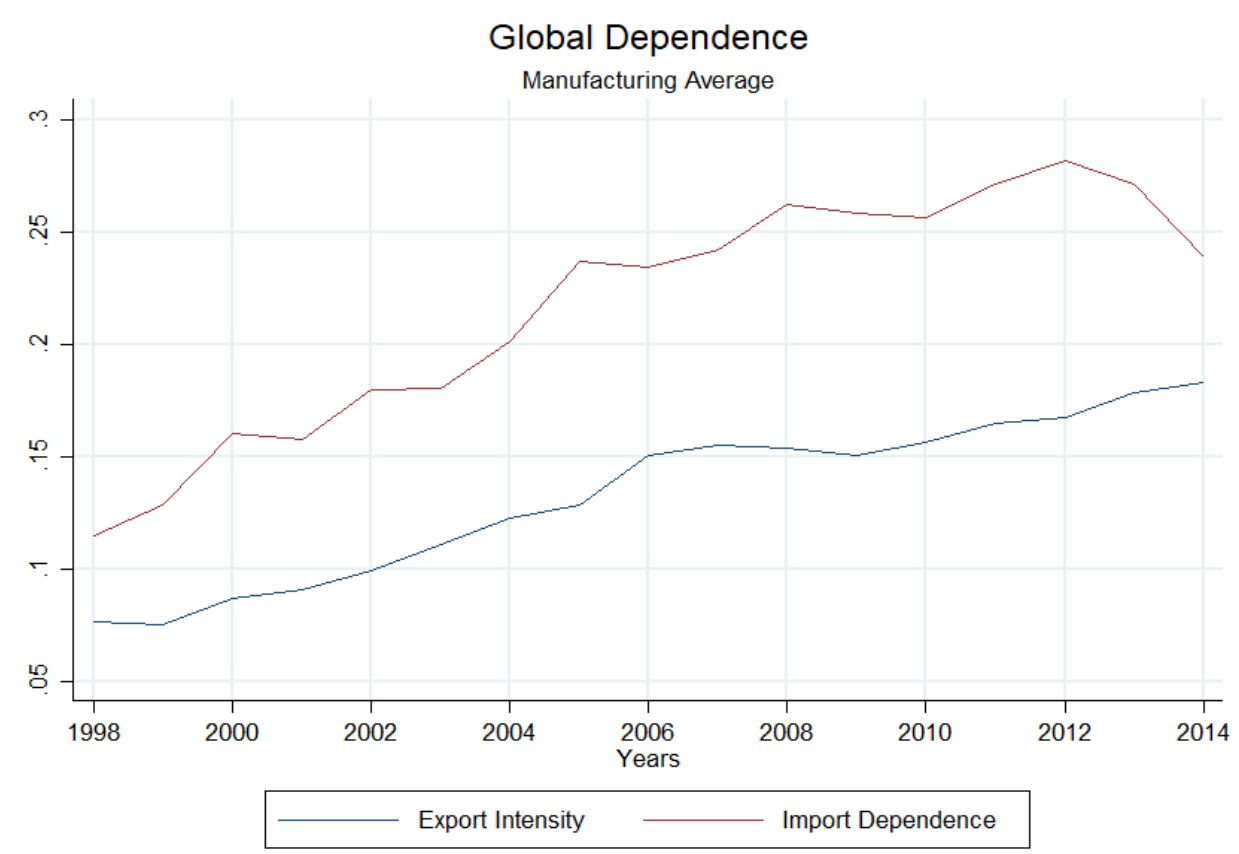

Figure 1: Trend of Export intensity and imported inputs dependence

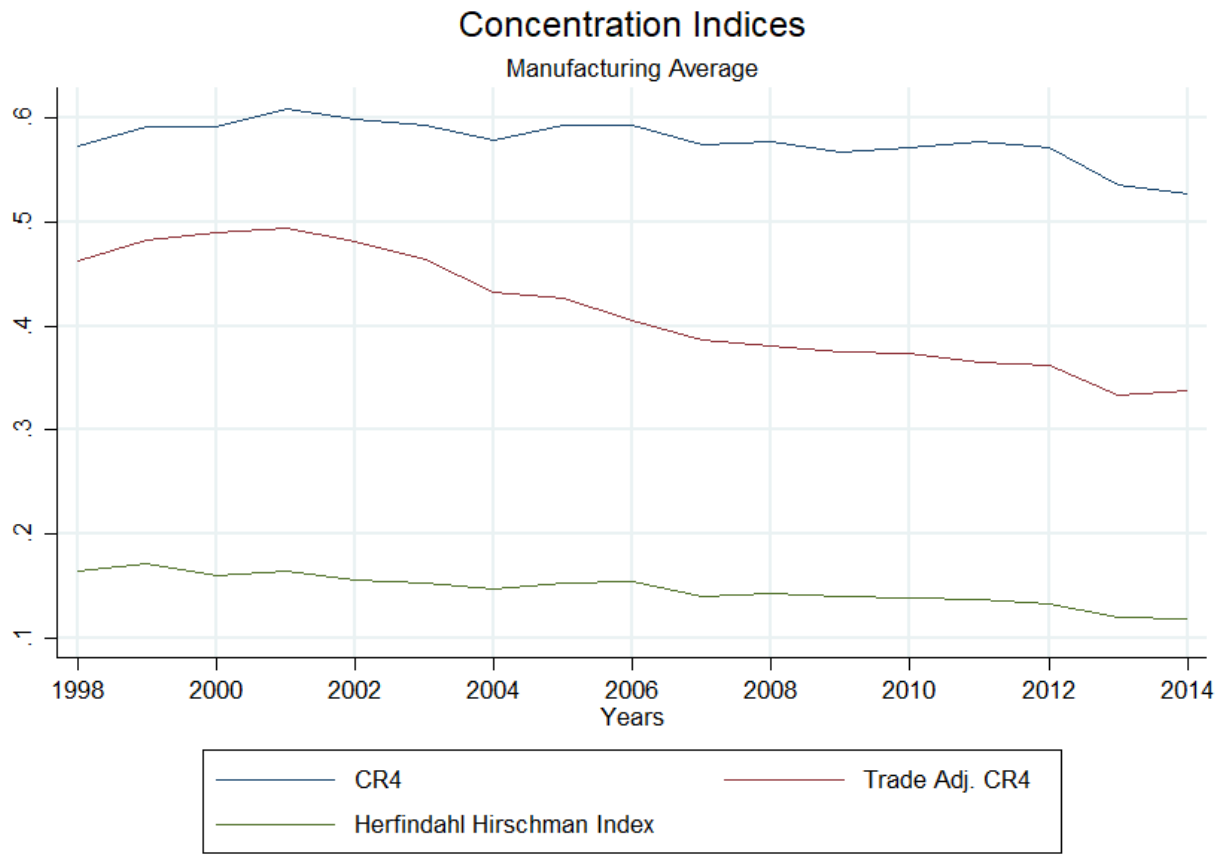

Figure 2: Trend of Market Concentration 


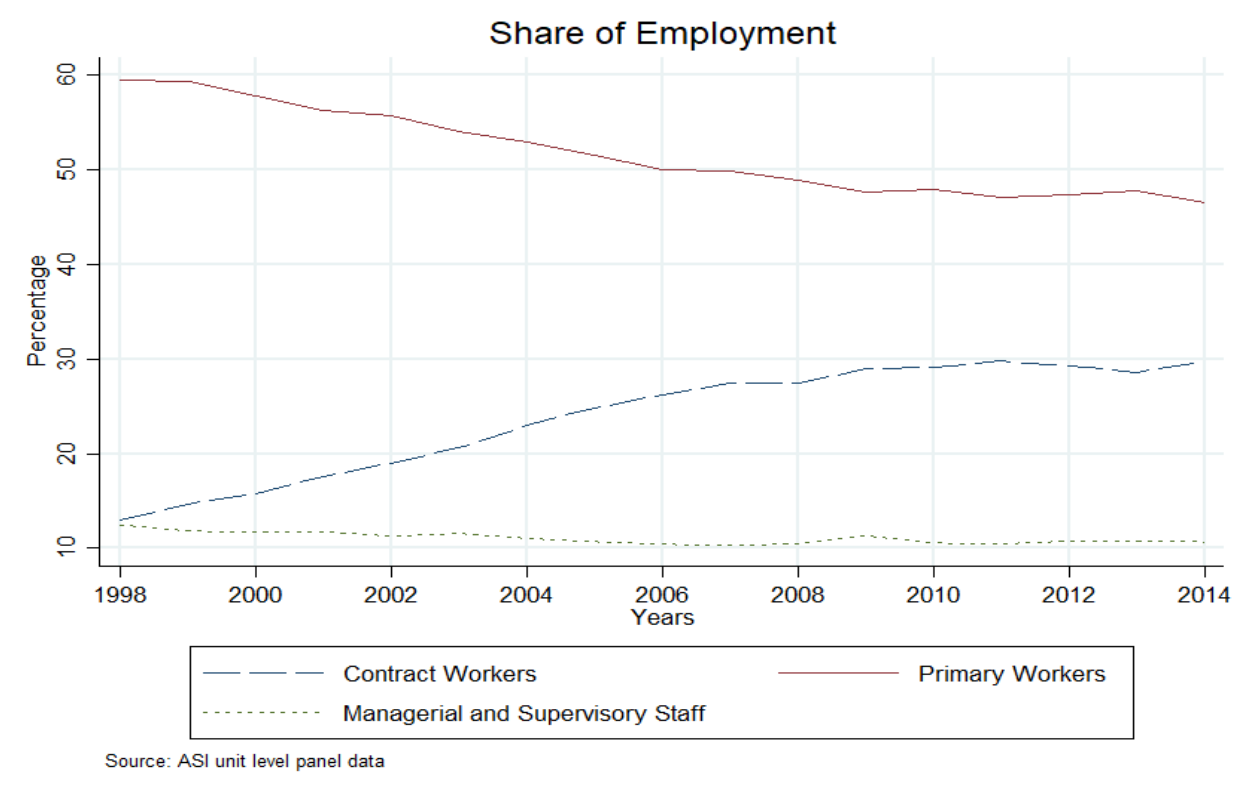

Figure 3: Share of Employment across categories

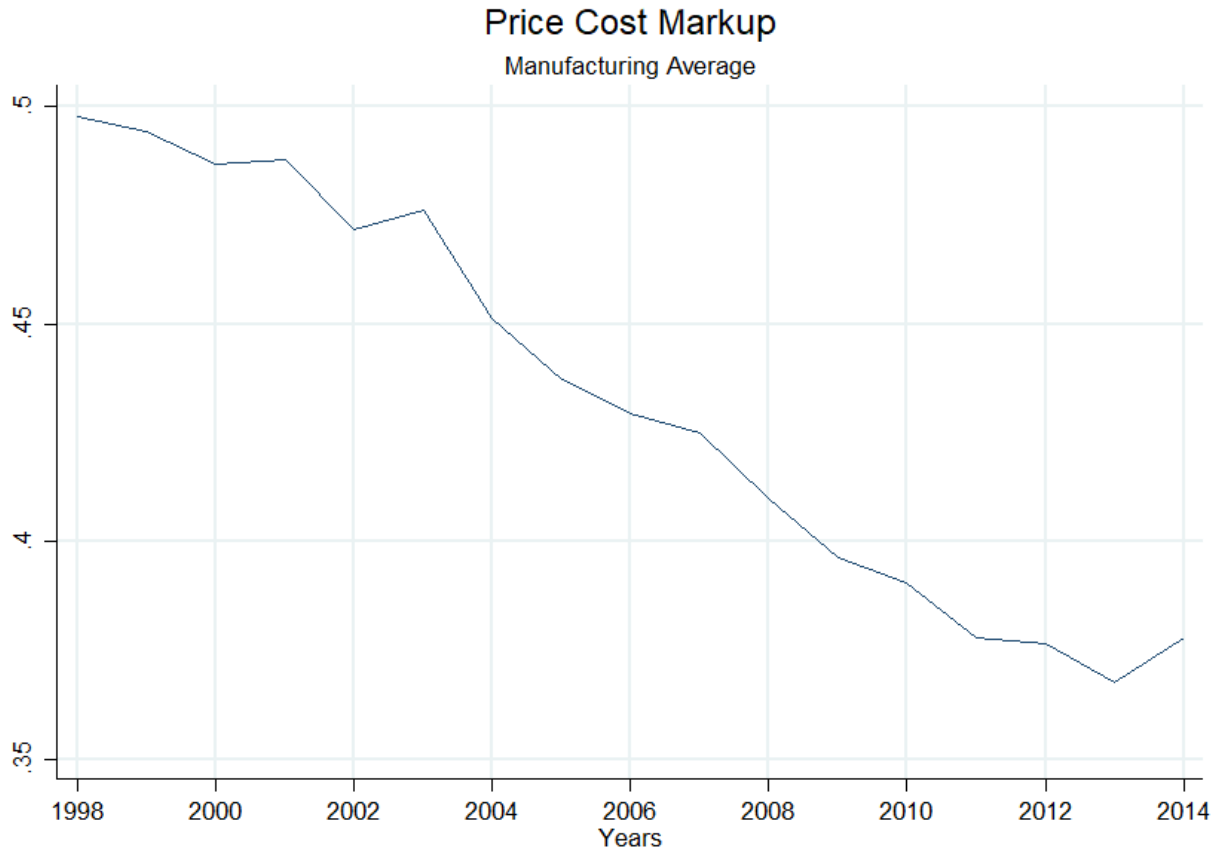

Figure 4: Trend of Price cost mark-up 


\section{Methodology}

In order to empirically investigate the effect of trade adjusted market concentration on the price cost mark-up and the contract workers' intensity, we employ the following empirical model:

1. $P C M_{i, t}=\beta_{0}+\beta_{1} T C R 4_{i, t}+\sum_{j=1}^{J} \alpha_{j} X_{i, j, t}+\beta_{2} \gamma_{i}+\beta_{3} \theta_{t}+\epsilon_{i, t}$

2. $C I_{i, t}=\beta_{0}+\beta_{1} T C R 4_{i, t}+\sum_{k=1}^{K} \alpha_{k} Z_{i, k, t}+\beta_{2} \gamma_{i}+\beta_{3} \theta_{t}+u_{i, t}$

$P C M_{i, t}$ represents the price cost markup for industry $i$ in time period $t$, where $\operatorname{PCM}_{i, t}=\left(\right.$ Sales $_{i, t}-$ Variable cost $\left._{i, t}\right) /$ Sales $_{i, t}$.

$C I_{i, t}$ denotes contract worker intensity for industry $i$ in time period $t$, where

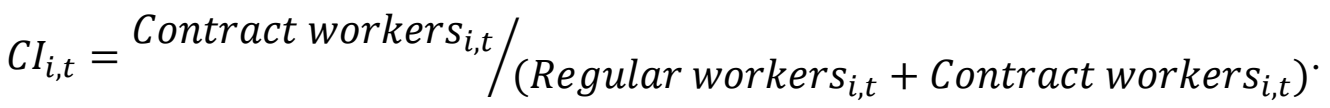

Our variable of interest the trade adjusted concentration ratio is being denoted by $\mathrm{TCR}_{\mathrm{i}, \mathrm{t}}$ which considers exports to, and imports from the domestic country in the market share component ${ }^{12}$. The trade adjusted market shares for TCR4 has been calculated following Bhattacharjee and Sindhwani (2017), $\mathrm{MS}_{\mathrm{l}, \mathrm{i}, \mathrm{t}}=\frac{\operatorname{Sales}_{\mathrm{i}, \mathrm{t}}^{1}-\text { Exports }_{\mathrm{i}, \mathrm{t}}^{1}}{\text { Total Sales }_{\mathrm{i}, \mathrm{t}}-\left(\operatorname{Total}_{\text {Exports }} \mathrm{i}_{\mathrm{t}, \mathrm{t}}-\text { Total Imports }_{\mathrm{i}, \mathrm{t}}\right)} 13$, where $M S_{1, i, t}$ denotes market share for firm $l$, in industry $i$ and time period $t$. TCR4 is calculated as the market share of top four firms in the total market share in the industry for a given time period, $T C R 4_{i}^{t}=\sum_{j=1}^{4} \frac{M S_{l, i, t}}{\sum_{l=1}^{N} M S_{l, i, t}}{ }^{14} \gamma_{\mathrm{i}}$ denotes the industry fixed effects and $\theta_{\mathrm{t}}$

\footnotetext{
${ }^{12}$ It has to be kept in mind that this formula of market share can only be used in calculating concentration ratios based on top four firms from Prowess database (which contains data for only large and medium sized firms) but not for the calculation of HH-Index, which requires data for all firms in a particular industry.

${ }^{13}$ Note that the fraction of market share will not add up to 1.

${ }^{14}$ It must be noted that the TCR4 market share equation can go in either direction to that of trade-unadjusted market shares. The denominator i.e., the effective sales in an industry can be lesser than or equal to or more than the total sales in an industry but the numerator which measures sales net of exports (in a firm) can be only lesser than or equal to sales. Thus, the direction of the ratio with respect to the trade-unadjusted market share is not straightforward.
} 
denotes the time fixed effects. As an alternative to the trade adjusted market concentration ratio, we have also taken the traditional concentration ratio (which does not take into account the concentration in a globalized economy) and tried to find whether variation in PCM or CI can be captured through the traditional measure. We have used the penalized-likelihood criteria, namely, AIC and BIC wherever necessary (possible), to choose between models of the trade-adjusted CR4 ratio and the traditional CR4 ratio.

\section{Control variables Measurement}

Capital-Output KOR is measured as the ratio of total gross fixed assets to total sales Ratio (KOR) in an industry.

Growth rate of GRS is taken as a proxy for market demand. sales (GRS)

Marketing Marketing expenses includes marketing expenditure, advertisement

Intensity (MKI) expenditure, promos and rebates. MKI is calculated as the total marketing expenses in an industry per unit of total sales.

$\boldsymbol{R} \& \boldsymbol{D}$ Intensity $\quad \mathrm{RND}$ measures the total $\mathrm{R} \& \mathrm{D}$ expenditure to that of the total sales in (RND) the industry. R\&D expenditure includes in-house $\mathrm{R} \& \mathrm{D}$ expenditure and expenditure on technology fees and royalties.

Intermediate IIR represents how the industry is dependent on the global market for Imported Input inputs. It is calculated using total inputs imported in the industry (raw Intensity (IIR) materials and capital goods) to total sales in that industry.

Export Intensity EIR is calculated as the share of export of goods and services to the $(\boldsymbol{E I R})$ total sales in the industry. It denotes how much of that industry's sales are dependent on global market.

Table 2: Control variables $(X)$ for Equation (1)

We have used a bunch of control variables ( $X$ and $Z$ denotes the matrix of control variables) to consider the time variant industry specific factors, which we have discussed in Table 2 and 3 respectively. In equation 1 (vide Table 2), KOR, MKI is used as proxy to measure the entry barriers in an industry. GRS is used as a proxy for market demand and RND for decreasing cost of production. EIR and IIR are considering the global dependence 
of an industry over time. In equation 2 (vide Table 3), FCI is taken as a proxy of the infrastructure input intensity of an industry and the rest of the control variables have already been discussed.

\section{Control variables Measurement}

Fuel consumption FCI is a proxy for the infrastructure input intensity of the firms and is intensity (FCI) computed by dividing costs of energy input by gross value of output.

Growth rate of GRS is taken as a proxy for market demand. sales (GRS)

Capital-Output KOR is measured as the ratio of total gross fixed assets to total sales Ratio (KOR) in an industry.

Intermediate IIR represents how the industry is dependent on the global market for Imported Input inputs. It is calculated using total inputs imported in the industry (raw Intensity (IIR) materials and capital goods) to total sales in that industry.

Export Intensity EIR is calculated as the share of export of goods and services to the (EIR) total sales in the industry. It denotes how much of that industry's sales are dependent on global market.

Table 3: Control variables (Z) for Equation (2)

One of the foremost challenges that an empirical study can potentially face is that of presenting a convincing identification strategy. Identification issues can arise due to reverse causality, or omitted variable bias, or both. We have tried to establish the identification strategy through multiple estimation methods. Ordinary Least Squares (OLS), under such circumstances, will be biased. Fixed-effect estimators can deal with unobserved heterogeneity associated with panel data. In our benchmark regression, we estimate both the models using fixed-effects estimator with robust standard errors, clustered at the industry level, to control for possible heteroskedasticity and autocorrelation within the same industry in different years. Fixed effect estimates can account for the time invariant factors like elasticity of consumption 
of the final goods, inherent skill intensity etc., and thus, ensure that our estimates are only capturing the variation within industries over time.

In the above models there may still be a problem of potential endogeneity of pricecost markup and contract-worker intensity. Highly concentrated industries may be the ones that are more likely to engage more contract workers or enjoy a higher price markup which could lead to reverse causality. Alternatively, it could be the low concentrated industries engage in more contract workers usage in the expectation that this would increase the competitiveness of the firms in that industry. Hence it is unclear which way the bias would go. If the same set of industries is most likely to engage in more $C I$ or more $P C M$ over the sample period, then the industry fixed effects would suffice. However, if there are timevarying factors that affect $C I(P C M)$ and TCR4 then it is necessary to instrument for TCR4. Unfortunately, valid instruments for TCR4 are unavailable, thus we use the Arellano-Bond GMM estimator ${ }^{15}$, which uses lags as instruments, to also address the potential endogeneity of TCR4 and other control variables ${ }^{16}$. This also considers the possible persistence of $P C M$ and/or $C I^{17}$. Murray (2006) points out that invalid instrument exacerbate the problem of estimation in the sense that they would result in inconsistent estimates and may lead to greater bias compared to ordinary least squares (OLS) estimates. Dynamic panel estimators solve this problem since they allow us to address the endogeneity issues by not having to find strictly exogenous instruments and, thus, it has become popular for recent empirical panel studies $^{18}$.

\footnotetext{
${ }^{15}$ These estimators are based, first, on differencing regressions or instruments to control for unobserved effects and, second, on using previous observations of explanatory and lagged-dependent variables as instruments (which are called internal instruments).

${ }^{16}$ Of course, if these variables are correlated over time any endogeneity that exists will persist. We have checked our model using Arellano-Bond AR2 test.

${ }^{17}$ The GMM approach is particularly useful in presence of persistence as it provides a general framework concerning issues of statistical inference and allows for convenient estimation of dynamic models without exhaustive details of the probability distribution of the data (Baltagi, 2001).

${ }^{18}$ For example, Chen et. al., 2009; Han et. al., 2016; Topalova and Khandelwal, 2011 to mention a few.
} 
As suggested by Arellano and Bond (2001), we use the difference GMM technique that gives unbiased and efficient estimates utilizing all possible orthogonality conditions. Note that in this IV approach (GMM), instruments are chosen from within the data set and those dated $(t-2)$ and beyond are valid if there is no serial correlation between the error terms. If the levels error is MA (1), one needs to consider higher order lags as instruments. Also, test for exogeneity of instruments in difference GMM performs better than in system GMM that generates additional instruments that weaken the Sargan/Hansen test statistic (Roodman, 2009). Moreover, the procedure allows us to perform Windmeijer (2005) sample correction to the standard errors. We also perform AR (2) test for second order serial correlation and Hansen test of over-identification restrictions to validate our GMM estimations.

\section{Empirical results and discussions}

The impact of trade adjusted market concentration (TCR4) on the profitability (contract intensity) of the industries using the fixed effects regression and the Arellano Bond GMM estimation is reported in Table 4 (Table 5). We have also used the traditional concentration ratio (CR4) in place of TCR4 to find whether the variation in profitability or the contract intensity can be captured by CR4. 


\begin{tabular}{|c|c|c|c|c|}
\hline & (1) & (2) & (3) & (4) \\
\hline & $\begin{array}{c}\text { Static Fixed Effects } \\
\text { Regression }\end{array}$ & $\begin{array}{c}\text { Dynamic AB } \\
\text { Regression }\end{array}$ & $\begin{array}{c}\text { Static Fixed Effects } \\
\text { Regression }\end{array}$ & $\begin{array}{c}\text { Dynamic AB } \\
\text { Regression }\end{array}$ \\
\hline & Price cost markup & Price cost markup & Price cost markup & Price cost markup \\
\hline $\begin{array}{l}\text { One-year lagged price } \\
\text { cost markup (L.PCM) }\end{array}$ & & $\begin{array}{c}0.350^{* *} \\
(3.03)\end{array}$ & & $\begin{array}{c}0.362^{* *} \\
(3.10)\end{array}$ \\
\hline $\begin{array}{l}\text { Trade adjusted CR4 } \\
\text { (TCR4) }\end{array}$ & $\begin{array}{l}0.194^{*} \\
(1.86)\end{array}$ & $\begin{array}{l}0.362^{* * *} \\
(2.06)\end{array}$ & & \\
\hline CR4 & & & $\begin{array}{l}0.236^{*} \\
(1.88)\end{array}$ & $\begin{array}{l}0.356^{*} \\
(1.91)\end{array}$ \\
\hline
\end{tabular}

\begin{tabular}{|c|c|c|c|c|}
\hline Constant & $\begin{array}{c}0.347^{\text {***** }} \\
(7.15)\end{array}$ & & $\begin{array}{c}0.281^{* * * *} \\
(3.79)\end{array}$ & \\
\hline Year fixed effects & Yes & Yes & Yes & Yes \\
\hline Industry fixed effects & Yes & No & Yes & No \\
\hline Control Variables & Yes & Yes & Yes & Yes \\
\hline No. of observations & 736 & 689 & 736 & 689 \\
\hline No. of groups & 46 & 46 & 46 & 46 \\
\hline No. of instruments & & 35 & & 36 \\
\hline $\mathrm{R}^{2}$ & 0.210 & & 0.210 & \\
\hline $\mathrm{AR} 1$ (p-value) & & 0.001 & & 0.000 \\
\hline $\operatorname{AR2~(p-value)~}$ & & 0.253 & & 0.268 \\
\hline Sargan Statistic ( $p$-value) & & 0.000 & & 0.000 \\
\hline Hansen Statistic (p-value) & & 0.245 & & 0.274 \\
\hline
\end{tabular}

\begin{tabular}{lll}
\hline AIC & -1982 & -1980 \\
\hline BIC & -1886 & -1884 \\
\hline
\end{tabular}

$t$ statistics in parentheses

${ }^{*} p<0.10,{ }^{* *} p<0.05,{ }^{* * *} p<0.001$

Standard errors are clustered at the industry level. Standard errors are heteroskedastic, and autocorrelation corrected.

Table 4: Regression result for equation (1)

We find positive statistically significant impact of TCR4 on profitability, both in the static fixed effects regression and the dynamic Arellano Bond GMM estimation. We also find that the variation in the profitability is also captured by CR4. Comparing the AIC and BIC of our benchmark results (Col. (1) and Col. (3)), we infer that the model with TCR4 is doing a better job in explaining the variation in profitability in the Indian formal manufacturing sector. 


\begin{tabular}{|c|c|c|c|c|c|c|}
\hline & (1) & (2) & (3) & (4) & (5) & (6) \\
\hline & \multicolumn{2}{|c|}{$\begin{array}{c}\text { Static Fixed Effects } \\
\text { Regression }\end{array}$} & $\begin{array}{c}\text { Dynamic AB } \\
\text { Regression }\end{array}$ & \multicolumn{2}{|c|}{$\begin{array}{c}\text { Static Fixed Effects } \\
\text { Regression }\end{array}$} & $\begin{array}{c}\text { Dynamic AB } \\
\text { Regression }\end{array}$ \\
\hline & Contract & Contract & Contract & Contract & Contract & Contract \\
\hline & Intensity & Intensity & Intensity & Intensity & Intensity & Intensity \\
\hline One-year lagged & & & $0.272^{*}$ & & & $0.274^{*}$ \\
\hline $\begin{array}{l}\text { Contract Intensity } \\
\text { (L.CI) }\end{array}$ & & & (1.84) & & & (1.94) \\
\hline
\end{tabular}

\begin{tabular}{|lccc|}
\hline Trade adjusted CR4 & $-0.263^{* *}$ & $-0.261^{* *}$ & $-0.183^{* *}$ \\
(TCR4) & $(-3.10)$ & $(-4.17)$ & $(-3.01)$ \\
\hline
\end{tabular}

\begin{tabular}{|c|c|c|c|c|c|c|}
\hline CR4 & & & & $\begin{array}{l}-0.0525 \\
(-0.80)\end{array}$ & $\begin{array}{c}-0.0603 \\
(-0.87) \\
\end{array}$ & $\begin{array}{l}-0.0418 \\
(-0.75)\end{array}$ \\
\hline Constant & $\begin{array}{l}0.470^{* * * *} \\
(16.52)\end{array}$ & $\begin{array}{l}0.421^{\text {***** }} \\
(18.73)\end{array}$ & & $\begin{array}{c}0.417^{\text {**** }} \\
(12.50)\end{array}$ & $\begin{array}{c}0.346^{* * * *} \\
(8.49)\end{array}$ & \\
\hline Year fixed effects & Yes & Yes & Yes & Yes & Yes & Yes \\
\hline Industry fixed effects & Yes & Yes & No & Yes & Yes & No \\
\hline Control Variables & No & Yes & Yes & No & Yes & Yes \\
\hline No. of observations & 782 & 736 & 690 & 782 & 736 & 690 \\
\hline No. of groups & 46 & 46 & 46 & 46 & 46 & 46 \\
\hline No. of instruments & & & 35 & & & 36 \\
\hline $\mathrm{R}^{2}$ & 0.567 & 0.561 & & 0.526 & 0.540 & \\
\hline $\mathrm{AR} 1$ (p-value) & & & 0.004 & & & 0.004 \\
\hline $\operatorname{AR2}(p$-value) & & & 0.300 & & & 0.247 \\
\hline $\begin{array}{l}\text { Sargan Statistic ( } p \text { - } \\
\text { value) }\end{array}$ & & & 0.000 & & & 0.000 \\
\hline $\begin{array}{l}\text { Hansen Statistic ( } p \text { - } \\
\text { value) }\end{array}$ & & & 0.165 & & & 0.208 \\
\hline AIC & & -1989 & & & -1947 & \\
\hline BIC & & -1893 & & & -1851 & \\
\hline
\end{tabular}

$t$ statistics in parentheses

${ }^{*} p<0.10,{ }^{* *} p<0.05,{ }^{* * *} p<0.001$

Standard errors are clustered at the industry level. Standard errors are heteroskedastic, and autocorrelation corrected.

Table 5: Regression result for equation (2)

From Table 5, we observe that TCR4 has a negative statistically significant impact on contract intensity, which means that with decreasing concentration in the industries, we find an increasing usage of contract workers, which goes along with our hypothesis. The result is robust even after accounting for the lagged dependent variable and using of IV and thereby controlling for endogeneity of the variables (Arellano Bond GMM estimation). We find that the variation in contract intensity cannot be captured by the traditional CR4 index. Other studies of contract intensity have drawn attention to that fact contract intensity is likely more in labour intensive industries in developing countries like India due to demand uncertainty in 
global markets for such products. We have done a sub-sample analysis (Table 6) where we have classified the industries in high capital intensity and low capital intensity industries. ${ }^{19}$ We find that the impact of TCR4 on contract intensity is statistically significant and negative for the group low capital-intensive industries but not for high capital-intensive industries. ${ }^{20}$ The CR4 index fails to capture the variation in contract intensity for both the subsamples. It can be observed from the AIC and BIC statistic (Col. (2) and (5) of Table 5) that our model with TCR4 is doing a better job in explaining the variation in contract intensity than the traditional measure.

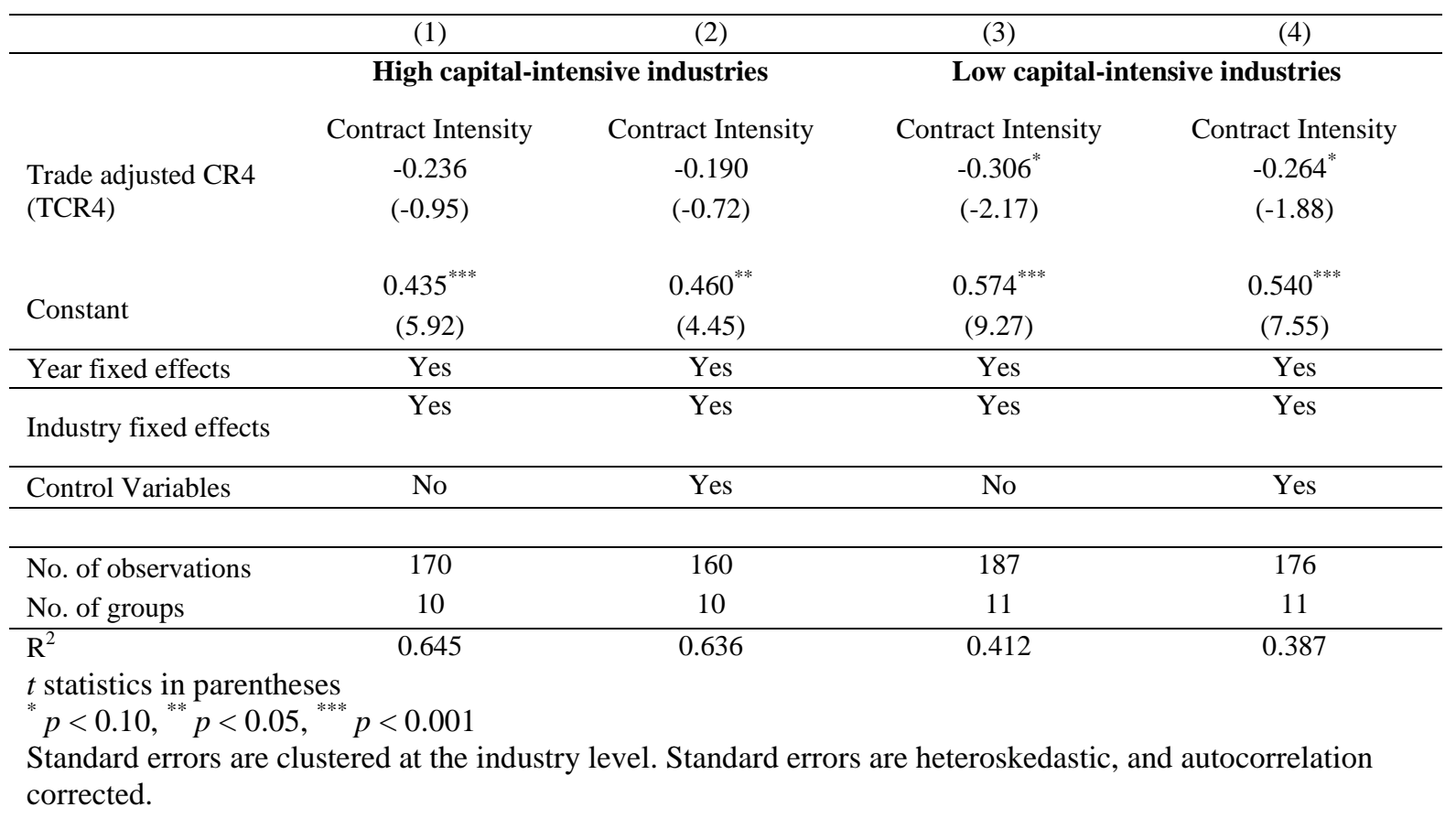

Table 7: Regression result for subsamples

\section{Conclusion}

It is widely accepted that globalization could adversely affect employment and other labour market outcomes. Most of the evidence has focused on the direct effects of globalization on labour demand, relative wages and the quality of jobs in developing countries. However, globalization could indirectly affect labour market condition (proportion of good jobs) through the product market channel. In our study of Indian manufacturing we have provided econometric evidence that globalization has encouraged manufacturing to

\footnotetext{
19 An industry is classified as high capital-intensive industry if its KOR is above the median value for the manufacturing sector throughout the decade and vice versa for less capital-intensive industries. The rest of the industries are classified as ambiguous. The list of industries is provided in Table A.1.

${ }^{20}$ This is consistent with the firm level evidence for contract worker intensity in labor intensive industries. See Ramaswamy (2015)
} 
relatively greater proportion of contract workers (temps in the US terminology). This outcome is shown to have come about in response to greater product market competition due to globalization. We find that the trade adjusted market concentration ratio has statistically significant impact on profitability and contract-worker intensity. Our benchmark result (fixed effects regression) is robust even after accounting for the lagged dependent variable and using IV in order to control endogeneity. Our sub-sample result is consistent with the proposition that greater cost competition will make manufacturing industries to use more contract labour. In summary, our study has provided suggestive evidence for indirect channels that explain why the faces are grim around the table in labour markets in developing countries. 


\section{References}

Acosta, P., \& Montes-Rojas, G. (2014). Informal jobs and trade liberalisation in Argentina. Journal of Development Studies, 50(8), 1104-1118.

Alfaro, L., \& Chari, A. (2010). India Transformed? Insights from the Firm Level 1988-2007. In Suman Bery, Barry Bosworth and Arvind Panagariya (editors), India policy Forum, Vol.6, 153-211, Sage Publications, New Delhi and Washington, D.C.

Arellano, M., \& Bond, S. (1991). Some tests of specification for panel data: Monte Carlo evidence and an application to employment equations, The Review of Economic Studies, 58 (2), 277-297.

Athreye, S., \& Kapur, S. (2006). Industrial concentration in a liberalising economy: A study of Indian manufacturing. The Journal of Development Studies, 42(6), 981-999.

Autor, D. H., Levy, F., \& Murnane, R. J. (2003). The skill content of recent technological change: An empirical exploration. The Quarterly Journal of Economics, 118(4), 1279-1333.

Baltagi, B. (2001). Econometric analysis of panel data. John Wiley \& Sons.

Bhandari, A. K., \& Heshmati, A. (2006). Wage inequality and job insecurity among permanent and contract workers in India: evidence from organized manufacturing industries. IZA Discussion Paper No.2097 available at http://ftp.iza.org/dp2097.pdf

Bhagwati, J (1993). India in Transformation: Freeing the Economy, Oxford: Clarendon Press.

Bhattacharjea, A., \& Sindhwani, F. (2014). Competition issues in the Indian pharmaceuticals sector. Center for Development Economics, Delhi School of Economics. New Delhi: CUTSCIRC available at https://cuts-ccier.org/pdf/Report-Pharmaceutical_Sector_Study.pdf

Chamarbagwala, R. (2006). Economic liberalization and wage inequality in India. World Development, 34(12), 1997-2015.

Chari, A., \& Gupta, N. (2008). Incumbents and protectionism: The political economy of foreign entry liberalization. Journal of Financial Economics, 88(3), 633-656.

Chen, N., Imbs, J., \& Scott, A. (2009). The dynamics of trade and competition. Journal of International Economics, 77(1), 50-62.

Currie, J., \& Harrison, A. (1997). Sharing the costs: the impact of trade reform on capital and labour in Morocco. Journal of Labor Economics, 15(S3), S44-S71.

Dix-Carneiro, R., \& Kovak, B. K. (2017). Trade liberalization and regional dynamics. American Economic Review, 107(10), 2908-46.

Dix-Carneiro, R., \& Kovak, B. K. (2019). Margins of labor market adjustment to trade. Journal of International Economics, 117, 125-142.

Goldberg, P. K., \& Pavcnik, N. (2003). The response of the informal sector to trade liberalization. Journal of Development Economics, 72(2), 463-496.

Goldberg, P. K., \& Pavcnik, N. (2007). Distributional effects of globalization in developing countries. Journal of Economic Literature, 45(1), 39-82. 
Goldberg, P. K., Khandelwal, A. K., Pavcnik, N., \& Topalova, P. (2010). Multiproduct firms and product turnover in the developing world: Evidence from India. The Review of Economics and Statistics, 92(4), 1042-1049.

Guadalupe, M. (2007). Product market competition returns to skill, and wage inequality. Journal of Labor Economics, 25(3), 439-474.

Han, J., Liu, R., Marchand, B. U., \& Zhang, J. (2016). Market structure, imperfect tariff passthrough, and household welfare in urban china. Journal of International Economics, 100, 220-232.

Hasan, R., Mitra, D., \& Ramaswamy, K. V. (2007). Trade reforms, labor regulations, and labor-demand elasticities: Empirical evidence from India. The Review of Economics and Statistics, 89(3), 466-481.

Morris, D. J., \& Hay, D. A. (1991). Industrial economics and organization: theory and evidence. Oxford: Oxford University Press.

Helpman, E., Itskhoki, O., Muendler, M. A., \& Redding, S. J. (2017). Trade and inequality: From theory to estimation. The Review of Economic Studies, 84(1), 357-405.

International Labour Office. (2015). World employment and social outlook: trends 2015. Geneva: International Labour Organization.

Kambhampati, U. (1996). Industrial concentration and performance: a study of the structure, conduct, and performance of Indian industry. Oxford University Press, New Delhi, India

Mazumdar, Dipak, Sarkar, Sandip, 2008. Globalization, Labour Markets and Inequality in India. Routledge, Oxon.

Menezes-Filho, N. A., \& Muendler, M. A. (2011). Labor reallocation in response to trade reform (No. w17372). National Bureau of Economic Research.

Mookherjee, Dilip. 1995. Introduction. In: Mookherjee, D. (Ed.), Indian Industry: Policies and Performance. Oxford University Press, Oxford, pp. 1-43.

Murray, M. P. (2006). Avoiding invalid instruments and coping with weak instruments. Journal of Economic Perspectives, 20(4), 111-132.

Pal, R. (2015). Dynamics of Firm's Competitive Behavior in Indian Manufacturing Industries: 1971-2010, in S. M. Dev (Ed.) India Development Report 2015. Oxford University Press, India.

Panagariya, A. (2008). India: The emerging giant. Oxford University Press.

Perloff, J., \& Carlton, D. (2005). Modern industrial organization. Pearson/Addison Wesley.

Ramaswamy, K. V. (1999). The search for flexibility in Indian manufacturing: New evidence on outsourcing activities. Economic and Political Weekly, 34(6), Pages 363-368, February 612, 1999.

Ramaswamy, K. V. (2006). State of Competition in the Indian Manufacturing Industry. A Functional Competition Policy for India, CUTS International, Jaipur and Academic Foundation, Delhi, 155-164.

Ramaswamy, K. V. (Ed.). (2015). Labour, Employment and Economic Growth: The Indian Experience. Cambridge University Press. 
Rodrik, D. (1999). Globalization and Labor, or: If Globalization is a Bowl of Cherries, Why are there so many Glum faces around the Table? Baldwin R.-Cohen D.-Sapir A.-Venables A, Market Integration, Regionalism and the Global Economy, CEPR/Cambridge.

Roodman, D. (2009). How to do xtabond2: An introduction to difference and system GMM in Stata. The Stata Journal, 9(1), 86-136.

Saha, B., Sen, K., \& Maiti, D. (2013). Trade openness, labour institutions and flexibilisation: Theory and evidence from India. Labour Economics, 24, 180-195.

Topalova, P., \& Khandelwal, A. (2011). Trade liberalization and firm productivity: The case of India. Review of Economics and Statistics, 93(3), 995-1009.

Windmeijer, F. (2005). A finite sample correction for the variance of linear efficient two-step GMM estimators. Journal of Econometrics, 126(1), 25-51. 


\section{Appendix}

\begin{tabular}{|c|c|}
\hline NIC & Industries \\
\hline 101 & processing and preserving of meat \\
\hline 102 & processing and preserving of seafood \\
\hline 103 & processing and preserving of fruit and vegetables \\
\hline 104 & vegetable and animal oils and fats \\
\hline 105 & dairy products \\
\hline 106 & grain mill products, starches and starch products \\
\hline 107 & other food and chemical products \\
\hline 108 & prepared animal feeds \\
\hline 110 & manufacture of beverages \\
\hline 120 & manufacture of tobacco products \\
\hline 131 & spinning, weaving and finishing of textiles \\
\hline 139 & other textiles, knitted and crocheted apparel \\
\hline 141 & wearing apparel, except fur apparel \\
\hline 142 & articles of fur; tanning and dressing of leather \\
\hline 152 & manufacture of footwear \\
\hline 162 & products of wood, cork, straw and plaiting materials \\
\hline 170 & manufacture of paper and paper products \\
\hline 181 & printing and service activities related to printing \\
\hline 192 & manufacture of coke oven products \\
\hline 201 & basic chemicals, fertilizer and nitrogen compounds, plastics and synthetic rubber \\
\hline 203 & manufacture of man-made fibres \\
\hline 210 & pharmaceuticals, medicinal chemical and botanical products \\
\hline 221 & manufacture of rubber products \\
\hline 222 & plastics products; jewellery; other manufacturing n.e.c. \\
\hline
\end{tabular}


231 manufacture of glass and glass products

239 manufacture of non-metallic mineral products n.e.c.

241 manufacture of basic iron and steel

242 manufacture of basic precious and other non-ferrous metals

$251 \quad$ structural metal products, tanks, reservoirs and steam generators

259 other fabricated metal products; metal working service activities

261 manufacture of electronic components

263 manufacture of communication equipment

264 consumer electronics, magnetic and optical media

265 measuring equipment; watches; electromedical; optical instruments; medical instruments and supplies

271 electric motors related; batteries and accumulators; other electrical equipments

274 manufacture of electric lighting equipment

275 manufacture of domestic appliances

281 general purpose machinery; computers and peripheral equipment

282 manufacture of special-purpose machinery

291 manufacture of motor vehicles

292 bodies for motor vehicles; trailers and semi-trailers

293 manufacture of parts and accessories for motor vehicles

301 building of ships and boats

302 manufacture of railway locomotives and rolling stock

309 manufacture of transport equipment n.e.c.

310 manufacture of furniture

Table A.1: List of three-digit industries 